International Journal of Social Science and Economic Research

ISSN: $2455-8834$

Volume:05, Issue:03 "March 2020"

\title{
WHY SENTIMENTS HAVE A PLACE IN THE LAW
}

\author{
Haddy Roche (Justice of Appeal) \\ Gambia Judiciary \\ DOI: 10.46609/IJSSER.2020.v05i03.012 URL: https://doi.org/10.46609/IJSSER.2020.v05i03.012
}

\begin{abstract}
Justice is a vital component of peace, and so judges are peace workers crucial to a peaceful, stable society. Yet, in this jurisdiction, the role of judges-especially the emotional components of their role remains to be explored. This article aims to start a change. It argues that although judges might often comment, and indeed have good basis for commenting that sentiments have no place in the law, the reality is that sentiments inspire laws and are the force behind laws. I argue that sentiments influence the creation, development and sustenance of laws, and influence a judge's application of the law. I discuss how sentiments give life to laws, sustain laws and develop laws. I then address the perils and benefits of encouraging sentiments in the law. I also recognize the alternate view which suggests that sentiments in the law are only valid when they are social sentiments for the social goals and social good, and therefore laws stemming from objectionable sentiments are not good laws, and should not be obeyed or applied. I nevertheless conclude that sentiments should be part of the law, because they often make a judge appear to be in tune, and will help make a litigant feel understood and validated, and society can often resonate with them. I however recommend that sentiments should not be part of the law at large, but should be subject to guidelines and limitations if they are to serve a useful purpose in the law.
\end{abstract}

Key words: peace and justice, role of judges, judges and emotion, judges and sentiments, law and sentiments

\section{Introduction}

Having taken the time to reflect and ponder on the view often expressed by some judges in this jurisdiction that sentiments have no place in the law, I was inspired to explore the topic. I was also inspired to explore the topic because I admit that I am one of those judges who sometimes tend to express sentiments, and I wanted to remind myself, and others who do the same, of the responsibility that goes with that. But I am also inspired to explore the topic, because there is 


\section{International Journal of Social Science and Economic Research}

ISSN: $2455-8834$

Volume:05, Issue:03 "March 2020"

hardly any literature in this jurisdiction that explores the topic or the emotional challenges judges can face. Judges (in this context also referring to magistrates), are often placed on a pedestal, and too far removed from the rest of society because of their privileged backgrounds or position in society. Yet, the truth is that judges are human, and some of them (including my very self), come from very modest backgrounds. Therefore, their humility, humanity and understanding should be highlighted and underscored so that they can develop a bond and understanding with the rest of society. Therefore, exploring the topic will invite more understanding for the decisions judges make, and will invite more understanding for the sentiments they express or don't express when they make those decisions. The truth is that, most often, judges are trying to meet the needs, interests and expectations of society when they express sentiments. Therefore, it is necessary to remind those who say sentiments have no place in the law, that sentiments in the law are often a reflection of the feelings, needs, interests and expectations of a society, of which judges are also members. Accordingly, it is useful for judges to indicate while making their decisions, that they are in tune with society, and that the feelings, needs, interests and expectations of society resonate with them. I also recognize that it is of utmost importance that judges do not compromise their impartiality, play to the gallery, or sacrifice their impartiality for sentiments. Exploring the topic critically, as I seek to do, will not only highlight the challenges judges face when it comes to expression of sentiments, it will also encourage a balanced approach to the expression of sentiments, which can only help increase the level of confidence in the judiciary.

\section{Why explore the topic?}

The benefits of exploring the topic are many. In line with the holistic approach to peace favored by peace philosophers such as Dietrich (2006), Galtung (1969) and Lederach (1998) among many others, it is clear that justice is a vital component of peace, and there cannot be meaningful, sustainable peace in the absence of an effective, vibrant justice system. Therefore, exploring an aspect of the justice system, with the aim of helping to improve it, is a significant contribution towards building meaningful, sustainable peace. Also, exploring the topic will include an explanation of the role of judges, which will help foster greater trust and understanding between the public and the judiciary. Such understanding and trust from the public will in turn encourage judges to be bolder in discharging their duties. An exploration of the topic will also encourage further discussion and research about the role of judges, which can lead to the development of more ideas for the effective performance of judicial duties and a better justice system. Such exploration, especially when developed further, can be a useful resource and guide for budding judges, and can add to the existing literature, and also be an essential contribution to the legal and judicial education system. It is certainly an encouragement 


\section{International Journal of Social Science and Economic Research}

ISSN: $2455-8834$

Volume:05, Issue:03 "March 2020"

to judges as it highlights an aspect of the challenges they face and seeks to improve their performance. Expression of sentiments can be cathartic, and therefore exploring the topic can be an addition to existing resources seeking the emotional development of the judges. Exploration of the topic will provide an opportunity for judges to self-reflect, look inward and make any changes they feel necessary in their approach regarding expression of sentiments.

Before going any further, I must however explain what I mean by "sentiments" so that the arguments I intend to forward can be put in proper perspective.

\section{What are sentiments?}

There are varying definitions of "sentiment". However, what most, if not all of the definitions have in common, is that it is a common human reaction pattern or disposition connected to emotions.

It has been defined as an opinion or feeling or emotion (Hovy, 2015), and Kline (2013) mentioned the definition provided by Cattell \& Child (1975), which view sentiments as 'Dynamic structures visible as common reaction patterns to persons, objects or social institutions and upon which all persons seem to have some degree of endowment'. (p.30)

McDougall (2015) explains sentiment as:

“... an organized system of emotional dispositions centred about the idea of some object. The organisation of the sentiments in a developing mind is determined by the course of experience;...The growth of the sentiments is of the utmost character and conduct of individuals and of societies; it is the organization of the affective and conative of life. In the absence of sentiments our emotional life would be a mere chaos, without order consistency, or continuity of any kind; and all our social relations and conduct, being based on the emotions and their impulses, would be correspondingly chaotic, unpredictable, and unstable. It is only through the systematic organisation of the emotional dispositions in sentiments that the volitional control of the immediate promptings of the emotions is rendered possible. Again, our judgments of value and of merit are rooted in our sentiments; and our moral principles have the same source, for they are formed by our judgments of moral value..." (Chapter 6, pp.164-165).

For McDougal, fear, love, hate, respect, self-regard, affection, sympathy, like, gratitude and kindness are all types of sentiment. 


\section{International Journal of Social Science and Economic Research}

ISSN: $2455-8834$

Volume:05, Issue:03 "March 2020"

The online English Oxford Living Dictionaries (n.d.) defines sentiment in a way that also encompasses the above definitions. It defines sentiment as "a view or opinion that is held or expressed", "general feeling or opinion", "a feeling or emotion" or "exaggerated and selfindulgent feelings of tenderness, sadness, or nostalgia".

From the above definitions, I will view sentiments as an inherent part of all human beings, but in varying forms and degrees. For example, where one might be kinder or more hateful in a particular situation than another might be. However, I believe that the list of sentiments above is not complete. I will also add compassion, empathy, understanding, patriotism, nationalism, racism, discrimination, admiration, appreciation, belief, notion, conception, conviction and inclination among others to the list.

\section{Possible foundations for the denial}

The view that sentiments have no place in the law has foundations otherwise it would not have been sustainable. One possible foundation is the belief that the role of judges is merely passive and limited to the application of laws and nothing more. This belief stems from the conventional view that there is indeed separation of powers, and so judges do not make laws, they merely apply the law. However, this conventional view is considered a myth by many, among whom Frank (1931) and Frank, (1973) who underscored how judges make law when they exercise discretion especially in contexts not spelt out by the law. Discretion is to be freely exercised by a judge in accordance with the particular facts and circumstances of the case in which it is to be exercised (Evans v Bartlam, 1937). The exercise of the same discretion can vary from cases to case, and so it provides many opportunities for judges to make law. There can be judicial law making even in the absence of the exercise of discretion by a judge. In our jurisdiction for example, a case like Sankung Sillah \& Sons Ltd v Gambia Ports Authority (1989, 1960-1993 GR) seemed to signal what was to come. It was held in that case that, though rules of court are not made for fun, the Court of Appeal can depart from the rules of procedure regulating appeals (mandatory rules for that matter) in "special circumstances", and after "careful scrutiny". "Special circumstances"

(p.349) and "careful scrutiny" were not defined, so it is clear that the court can define "special circumstances" and engage in "careful scrutiny" as it sees fit, and in such circumstances will also inevitably be making law.

Although in the Sankung Sillah case the Court of Appeal was of the view that special circumstances did not exist to warrant a departure from the mandatory rules of procedure, and so did not depart from mandatory rules of procedure in that case, in subsequent cases, for example 


\section{International Journal of Social Science and Economic Research}

ISSN: $2455-8834$

Volume:05, Issue:03 "March 2020"

in the case of Haro Company Limited v Ousman Jallow (2003, 2002-2008 GLR), the Court of Appeal complemented its earlier decision in the Sankung Sillah case and held that even though rules of court are meant to be obeyed, the court can, for "very good reasons and in really exceptional situations" depart from the rules of procedure (p.141). Again, even though the court also held that such exceptional situations would include where it can be held that an irregularity has been waived or that it does not materially affect the merits of the case or it will engender a miscarriage of justice to allow it vitiate a process, there was no specific guide as to what would amount to "very good reasons" or "really exceptional situations", and there was no limit imposed on the use of the terms "very good reasons" and "exceptional situations". Consequently, the Court of Appeal and indeed the Lower courts are again free to apply them to the facts of each case as they see fit, and in the process make more laws. The Court of

Appeal in the Haro case added that "..A court should strive to do substantial justice and should not allow itself to be prevented from doing so by procedural rules..” (p.141).

This further indicates that judges now have more flexibility, and would have more opportunities to make more laws in the name of "substantial justice". Consequently, in Antoine Banna v Ocean view Resort Limited (2003, 2002-2008) GLR, the Court of Appeal had more flexibility and did not even impose conditions such as "exceptional situations" or "for very good reasons" to depart from mandatory rules of court. It merely stated that

“...Rules of Court even if mandatorily couched are not sacrosanct but permissive and will be applied purposively and practically to meet the justice of the situation..." (p.13).

This indicates that in the name justice- and the definitions of justice are many and varied (Harvey \& Braun, 1996), the courts can depart from the mandatory rules and in the process inevitably make laws. Therefore, in this jurisdiction, the courts' powers to make laws are ever increa sing. Bearing in mind that decisions of appellate courts bind Lower courts, it is clear that all courts have the opportunity to make laws, and they do make laws based on the appellate courts' decisions (especially about the exercise of discretion) and how they are subsequently interpreted.

The above cases cited are just few examples of opportunities for judicial law making. There are other examples of judicial law making, such as when judges make law through the interpretation of statutes, or when they fill in the gaps in statutes. However, there is no need to further buttress the point, because I think I have already made the point, and made it is clear, that judges do not only apply the law, they also make laws. And so, one of the foundations for the view that sentiments have no place in the law has been negated. It is important to note that in all the above cited cases where there was judicial law making, the judicial law making was not made out of 


\section{International Journal of Social Science and Economic Research}

ISSN: $2455-8834$

Volume:05, Issue:03 "March 2020"

thin air. It was triggered by sentiments like justice and fairness. Therefore, the fact that sometimes judges make law can be a good thing, especially if such law making is not found perverse, absurd, unreasonable, unnecessary and biased having regard to the evidence and facts before the court.

Another possible foundation is the requirement that judges must be independent and impartial. There is no place for favoritism or bias in the courts. In this jurisdiction, like in many jurisdictions, judges take and subscribe the Oath for the Due Execution of Office which is set out in the First Schedule to the Oaths Act (1965) Laws of The Gambia. They swear to execute their functions without fear or favor, affection or ill-will. The symbol of justice (and we have one at the main entrance of our Superior Courts Complex), is most often a blindfolded figure often female) with balancing scales not capable of seeing anything that could influence it and prevent it from balancing the scales and doing justice. The oath and symbol notwithstanding, there is the argument that for the most part, judges decide cases from their own personal and subjective grounds-including instincts, assumptions, haunches, values, beliefs, politics and all. The point made by Frank (1931), was that a judge should not be a mere thinking- machine, but should also strive for ideals in the law. Of course, striving for ideals in the law, like striving for ideals elsewhere, would also invite bias, prejudice, favor, affection and even ill-will. Bandes (2011), while encouraging judges to use some moral imagination, moral reasoning and empathy in their judgments, also recognized the need for safe guards to avoid partiality of perspective and bias. D' Amato (2011), also contends that a judge's sense of justice comes first, and then interpreting the law comes second. Therefore, the law will be interpreted according to the judge's sense of justice. Going by Anthony, I believe it will also be difficult, if not impossible for a judge to comply with the terms of his or her Oath of Office, because a judge's sense of justice would be personal and subjective, and would inevitably also include some bias, prejudice, affection or even ill-will- whether consciously or not.

A further reason why a judge might state that sentiments have no place in the law is because he or she might not want to give the impression that it is not only the application of the law that led to his or her decision. D'Amato (2011) is of the view that “...... Any judicial opinion is a carefully constructed exercise in legal rhetoric, designed to convince the reader that the judge had no choice, that 'the law' determined everything. (It's as if the judge is saying to the losing party, 'blame the law, not me..." (p.11)

Therefore, a judge would like to show his or her committed to the law (or appearance of commitment to the law), and so would make it known that sentiments have no place in the law, when the reality would be something different. D'Amato (2011) also points out that a judge out 


\section{International Journal of Social Science and Economic Research}

ISSN: $2455-8834$

Volume:05, Issue:03 "March 2020"

of fear of criticism, or wanting to give the appearance of his or her commitment to the law, would want to make it appear that his or her decision was compelled by the law, even though the reality is that his or her feelings and disposition were not excluded from the decision, and he or she was in fact the one who chose to decide the way he or she decided, not the law.

While the above contentions might be based on the personal experiences of the respective authors and therefore valid, my personal experience, and what I would advocate for, is that there can be judges who are genuinely committed to the law, and would in fact be guided by the law in reaching their decision, but their decision being guided by the law does not necessarily mean that it would be devoid of emotions. Therefore, my contention is that a judge can be guided by both the law and emotions in reaching a decision, and I will disagree with the general contention that judges would always reach their decisions even before referring to the law.

However, there are many other reasons for denying that sentiments have a place in the law. For example, it has been argued that the history of rationality and dispassion in the law is one of the reasons for resisting sentiments in the law (Abrams \& Keren, 2010). Indeed, there is the fear that judges might express sentiments for reasons which are objectionable, like supporting the biases or prejudices of particular litigants (Bandes, 2017). There is also the possibility that judges might express sentiments in ways that are objectionable, for example they might use too harsh or offensive language or expression in expressing sentiments. Frank (1931) admits that there are allegations that sentiments corrupt the law and destroy the predictability of the law, and would therefore lead to uncertainty and chaos in the law. He however dismissed that allegation, and pointed out that the law is far from predictable because of the discretionary and interpretative powers of judges.

There is also the fear that if sentiments are encouraged in the law, judges will not be insulated from pressure from the political branches or from undue sympathy with one or more of the parties (Abrams \& Keren 2010). However, some would doubt that judges were ever really insulated from pressure from political branches or from undue sympathy with one or more of the parties (Frank, 1931; Frank, 1973). It should not be forgotten that judges are merely human and susceptible to human weaknesses. What should matter is that such human weaknesses are kept in check, and are not allowed to pervert the truth, the evidence, the law and justice in the case (Frank, 1931). In any event, despite the resistance highlighted, sentiments are sine qua non of the law, and so Bandes (1999) observed that the law is full of emotional content.

\section{Sentiments as inspiration for the law}




\section{International Journal of Social Science and Economic Research}

ISSN: $2455-8834$

Volume:05, Issue:03 "March 2020"

The Universal Declaration of Human Rights 1948, which is the inspiration for many constitutions and laws, including the constitution and laws of The Gambia, was largely inspired by sentiments stemming from the horrors of war and abuse of human rights. These sentiments are displayed in the preamble as follows:

Whereas recognition of the inherent dignity and of the equal and inalienable rights of all members of the human family is the foundation of freedom, justice and peace in the world,

Whereas disregard and contempt for human rights have resulted in barbarous acts which have outraged the conscience of mankind, and the advent of a world in which human beings shall enjoy freedom of speech and belief and freedom from fear and want has proclaimed as the highest aspiration of the common people,

Whereas it is essential, if man is not to be compelled to have recourse, as a last resort, to rebellion against tyranny and oppression, that human rights should be protected by the

rule of law...

Whereas peoples of the United Nations have...reaffirmed their faith in the fundamental rights, in the dignity and worth of the human person and in the equal rights of men and women and have determined to promote social progress and better standards of life in larger freedoms... Now, therefore,

The General Assembly,

Proclaims this Universal Declaration of Human Rights as a common standard of achievement for all peoples and all nations...” (paras. 1,2,3,4,7-10).

The fundamental rights recognized by the Universal Declaration of Human Rights as prompted by the sentiments expressed in the preamble, are also recognized and protected in our 1997 Constitution which was passed after the coup d'état of a government that had been in power for thirty years, is also laden with sentiments in its preamble.

The preamble to our 1997 Constitution states:

"In the name of God the almighty.

We the people of The Gambia have accomplished a great and historic task. We have had our say on how we should be governed. For this Constitution contains our will and resolve for good governance and a just, secure and prosperous society.

Our hopes and aspirations as a people were reflected in the enthusiasm and zeal with which we embarked on nation building on the attainment of independence. The self-perpetuating rule of the recent past, however, soon gave rise to the abuse of office and related vices which negated the total welfare of the Gambian people. The sovereign people of The Gambia therefore endorsed the change of government... to rectify such evils. 


\section{International Journal of Social Science and Economic Research}

ISSN: $2455-8834$

Volume:05, Issue:03 "March 2020"

This Constitution provides for us a fundamental Law, which affirms our commitment to freedom, justice, probity and accountability. It also affirms the principle that all power emanates from the sovereign will of the people.

The fundamental rights and freedoms enshrined in this Constitution, will ensure for all time respect for and observance of human rights and fundamental freedoms for all

The Constitution guarantees participatory democracy that reflects the undiluted choice of the

people...

As we usher in the Second Republic and beyond we give ourselves and generations of Gambians yet unborn this Constitution as a beacon of hope for peace and stability in our society and the good governance of The Gambia for all time

In this spirit, we continue to pledge our firm allegiance to our beloved Country and pray that the Great God of Nations will keep us all ever true to The Gambia" (paras. 1-8).

From the preamble, and its contents, it appears the 1997 Constitution (albeit its critics), was created as a result of the sentiments of the day which resonated with the public. These sentiments are what András (2016) called "constitutional sentiments". András highlights how sentiments (emotions) have a role in the construction of legal institutions such as constitutions and the law they generate. He referred to the American and French constitutions of the $18^{\text {th }}$ Century as reflecting the galvanizing power of emotions, and showing the reality that constitutions are created through emotionally driven processes and reflect the public sentiments of the day. He observed that the stability of modern liberal constitutions such as the American and French constitutions can be partially explained by their resonance with the emotional cultures within which they operate. The preamble to the European Convention on Human Rights (1950), which inspires the national laws of European member states, also draws inspiration from the Universal Declaration of Human Rights, and also contains sentiments in stating the reasons for its creation. Nearer to home, the African Charter on Human and Peoples Rights (1986) was inspired by both the Universal Declaration of Human Right and the European Convention of Human Rights (1950), and it is also loaded with sentiments, emphasizing the need to make such rights relevant to the African context. Article 1 of Part1 of the African Charter on Human and Peoples Rights implores member states to take legislative and other measures to ensure that the rights stipulated in the Charter are given effect nationally. Therefore, they are also meant to inspire the national laws. The preamble to the Charter states that: 


\section{International Journal of Social Science and Economic Research}

ISSN: $2455-8834$

Volume:05, Issue:03 "March 2020"

"The African States members of the Organization of African Unity,

Parties to the present Convention entitled "African Charter on Human and Peoples Rights...

Considering the Charter of the Organization of the African Unity which stipulates that freedom, equality, justice and dignity are essential objectives for the achievement of the legitimate aspirations of the African peoples;

Reaffirming the pledge they solemnly made ... to eradicate all forms of colonialism from Africa, to coordinate and intensify their cooperation and efforts to achieve a better life for the peoples of Africa and to promote International cooperation having due regard to the Charter of the United Nations and the Universal Declaration of Human Rights...

Taking into consideration the virtues of their historical tradition and the values of African civilization which should inspire and characterize their reflection on the concept of human and peoples' rights...

Conscious of their duty to achieve the total liberation of Africa, the peoples of which are still struggling for their dignity and genuine independence and undertaking to eliminate colonialism, neo-colonialism, apartheid, Zionism and to dismantle aggressive foreign military bases and all forms of discrimination,, language, religion or political opinions...

Firmly convinced of their duty to promote and protect human and people's rights and freedoms and taking into account the importance traditionally attached to these rights and freedoms in Africa,

Have agreed as follow... (paras 1,3, 4, 5, 9, 11 and 12)

Bandes (2017) alludes to the fact that the European Court of Human Rights has been known to interpret the European Convention on Human Rights drawing from contemporary moral values and the evolving nature of modern society.

Consequently, constitutions and indeed the laws they generate, will also change when sentiments change. In this jurisdiction for example, a change of government and change of sentiments in December 2016 have already led to changes to certain provisions of the Constitution, and there is talk of a Constitutional Review Commission to be established with a view to coming up with a new Constitution that would hopefully reflect the current wishes and aspirations of The Gambian people. Of course the expected wishes and aspirations of the Gambian people will be based on sentiments.

Only a relative stability of the law is required ( $\operatorname{Raz} 2009)$. Therefore, it is a good thing that laws change to keep up with changing times. Many years ago, many would not have believed that there would be laws legalizing same sex marriages in Western countries, yet now same sex marriages are recognized in some US states and in many European countries (Eskridge Jr., 1999). In Saudi Arabia, women were legally allowed to vote only as recent as 2015, and they 


\section{International Journal of Social Science and Economic Research}

ISSN: $2455-8834$

Volume:05, Issue:03 "March 2020"

were allowed to drive only about a year ago by a law passed in 2017 (Jones, 2017). Although it must be pointed out that, as I write the law allowing women to drive is yet to be operational, the said two new laws favoring women were undoubtedly inspired by changing sentiments about women in that country. Therefore, the argument by Frank (1931) is that man was not made for the law, but the law was made for man. For example, the 1997 Constitution of The Gambia was meant to replace the first constitution of the republic, (the 1970 Constitution of The Gambia), which after the 1994 military coup people found wanting in some regards, such as its lack of term limits on the presidency, educational qualifications for the president, qualification for citizenship, dual citizenship, the age of voting among others. And some (not all) of these concerns were addressed in the 1997 Constitution. For example, the concern for term limits on the presidency was not addressed in the 1997 Constitution, and this was underscored by (Jobarteh, 2017), who therefore stressed the need to review the 1997 Constitution to be in line with public sentiments.

Our criminal and civil laws (which are all subject to the Constitution), are a reflection of the needs and aspirations of the people for a peaceful and stable society based on their requirements of a peaceful and stable society. Rowell (2018) presents results of a study in the US, showing that even though people's beliefs and aspirations for the law would sometimes differ from the actual law passed, in general, people think that the law should be whatever they think it should be, and that people's beliefs about the law can be predicted more accurately by knowing what their aspirations for the law are than by knowing the particular law.

Rowell's study confirms that people believe their laws should reflect their aspirations and beliefs. However, Rowell also confirmed that it is not always the case that a law will reflect the aspirations and sentiments of the people. There could be laws that are against the wishes of the people (the majority), and do not lead to a peaceful and stable society. For example, there could be objectionable laws that seek to marginalize opposition parties, or prevent certain members of the public from running for the office of president and lead to unrest and instability. Recently, there have been media reports of unrest in Senegal, among them a report by Ba, Christenssen, McAllister,\& Roche (2018, April, 19) of Reuters, which say that with barely less than a year to the next presidential elections, a bill proposed by the sitting president and his ruling party, was passed (in a parliament where the ruling party has the majority seats) requiring all presidential candidates to obtain the signatures of about one percent of registered voters in each of the 14 regions in Senegal. This means that a total of 60,0000 signatures must be obtained by a person who wishes to run for the office of president. Ba et al (2018) report that the argument by critics is that the law aims to reduce and silence the number of opposition candidates as it will cost a lot 


\section{International Journal of Social Science and Economic Research}

ISSN: $2455-8834$

Volume:05, Issue:03 "March 2020"

of money and resources to obtain the signatures of 60,000 registered voters, and so most opposition candidates might not be financially capable of meeting the requirement, thus leaving the president with fewer challengers.

Here at home, The Independent Electoral Commission (Amendment) Act 2015 passed under the previous government which held the majority in parliament, and which required aspiring presidential candidates to deposit the sum of D500,000.00, faced sentiments of opposition (Ndabaneh,2017), and hence was amended by the Elections (Amendment) Act 2017 tabled by the present government.

The Apartheid Laws of South Africa which ensured racial separation were not a reflection of the aspirations of the majority of South Africans who are black. Yet, they no doubt stemmed from sentiments (objectionable sentiments) based on a feeling of superiority and entitlement over black South Africans, and a desire to ensure their permanent segregation from white South Africans (Landis, 1961 \& 1962). The racist Jim Crow Laws, and other racist laws that existed in the USA, were also no doubt based on objectionable sentiments which supported the belief that white Americans were superior to black Americans, and hence sought to separate blacks from whites (Pilgrim, 2000).

Not only is the law rooted and created from sentiments pertaining to the aspirations and wishes of people (objectionable and non-objectionable), it is also expected to be applied by the courts in accordance with the aspirations and wishes people based on their sentiments. Hence Brobbey CJ (as he then was), in Sallah \& Ors v Clerk of National Assembly \& Ors (2002-2008) GLR commented that: "Every court, including this Supreme Court, is accountable to the people of the country for whom it provides services and on whose behalf the court exist and operate. We administer justice to ensure the realization of the aspirations of the people...." (p. 239)

Certainly, this statement indicates to me, that sentiments do have a place in the administration of the law. The court in administering the law, would aim to realize the aspirations of the people. The court will most certainly take into account the operating sentiments, and will also inevitably be guided by those sentiments-whether or not it chooses to express them. The Supreme Court of the Gambia, recently, in delivering its judgment in the case of The Gambia Press Union \& Ors v The Attorney General (2014), aligned itself with sentiments mostly from the media fraternity and civil society organizations, about the need for less repressive media laws and for more media freedom in The Gambia. It found that criminal defamation, libel, and the Information and Communications Act relating to internet offences, hitherto considered draconian were unconstitutional. The law on sedition was also declared unconstitutional as long as it does not 


\section{International Journal of Social Science and Economic Research}

ISSN: $2455-8834$

Volume:05, Issue:03 "March 2020"

relate to the president. Following the decision, the lawyer for the Gambia Press Union reportedly publicly expressed relief that at last speech will no longer be criminalized in The Gambia (Sanneh, 2018). No doubt, despite the mixed feelings reported by the Media Legal Defence Initiative (2018), the decision was a giant step in the right direction- towards eventually satisfying all the needs, interests and expectations of the media fraternity, civil society organizations and society at large, and so deserves to be hailed.

As the Chinese saying goes, "a journey of a thousand miles begins with a single step".

Therefore, the significance of the Supreme Court judgment cannot be over emphasized.

As a matter of fact, the BBC (2018) has just reported that the Republic of Ireland overwhelmingly voted to liberalize its strict abortion laws, which were passed in 1983 through a constitutional amendment banning virtually all abortions in Ireland (Weinstein, 1993). No doubt the vote was due to changing sentiments, and the Irish legislature must now take these changing sentiments into account in revising the 1983 laws, to make them more liberal. Therefore, legislators who make laws are bound by the wishes, aspirations and expectations of the people who elected them, and they should pass laws that reflect the wishes, aspirations and expectations of their constituents, and not the wishes, aspirations and expectations of their political parties. Laws passed by parliament should reflect the wishes of voters. Otherwise a legislator could lose his or her seat. For example, a study by Masket \& Green (2011) found that in the USA in 2010, a number of members of the Democratic Party who voted for Obamacare against the wishes of their constituents lost their seats in the midterm elections. Of course legislators and indeed members of the executive might support the creation of laws that goes against the aspirations and expectations of voters. However, most often when they do, there will be divisions and tensions in society leading to the changes that people might want. This being the case, the likes ofKhaza (2016) who is supported by Newkirk 11 (2017), will argue that in the 2016 US presidential elections, the unpopularity of Obamacare helped put President Trump in the White House and cost Hillary Clinton the presidency.

Of course, the situation is different in a country without free and fair elections, as is perceived to be the case with most developing countries often recovering from conflict or in conflict (Ndulo \& Lulo, 2010). However, although it is true that in countries without free and fair elections the wishes and aspirations of people might not impact the vote, it is also true that in such jurisdictions there is no peace and stability (Ndulo \& Lulo, 2010). And so in such cases, it is still sentiments (albeit objectionable sentiments), that would steer and guide the arms of government, including the legislature and the judiciary. 


\section{International Journal of Social Science and Economic Research}

ISSN: $2455-8834$

Volume:05, Issue:03 "March 2020"

\section{The support for sentiments}

As I have argued that laws are inspired and brought to life by sentiments. I should also point out that laws which are inspired and brought to life by sentiments of people on whose behalf they are passed, will serve better purpose and will be more useful and practical than laws which are passed willy-nilly to satisfy the whims and caprices of a selected few, who although might have sentiments, those sentiments will be considered objectionable. It is important that laws serve useful purpose, and being that they are generally inspired by sentiments which underlie the needs aspirations and expectations of the people on whose behalf they are passed, they should be useful. Therefore, sentiments play a very important role in making laws useful. And even though the whims and caprices of such selected few might be based on sentiments, as I have stated, they will still be objectionable sentiments, and will inevitably produce objectionable laws, and will therefore serve no useful purpose. In the end such objectionable laws will harm those who passed them (more often, but not always the minority) who passed them, and will inevitably lead to steps towards desired changes-like a change of regime. The well-known Arab Spring and fall of dictators like Muammar Gaddafi and Saddam Hussein comes to mind. The present intractable conflict in Syria (Roche, 2017), which started in 2011 as a result of protests against President Assad's regime is also another example. Another example nearer to home, is what happened to the former president of Burkina Faso Blaise Campaore in 2014 (Hirschel- Burns, 2015). Campaore, who after having served as president for twenty-seven years, tried to pass a law to change the electoral laws and abolish presidential term limits (Hirschel-Burns, 2015). This prompted widespread protests organized by people of his country leading to his removal (Hirschel-Burns, 2015). And media reports, including those by (Aljazeera, 2018), show that Burundi has been unstable for a while now because of opposition to the then proposed law (which has since passed in a referendum on $21^{\text {st }}$ May 2018), that extends the term of the president from five to seven years, meaning that the current president can be in power until 2034 (Aljazeera, 2018).

Of course, there are other African presidents who have stayed in power for decades due to laws that favour them- the presidents of Congo Brazzaville and Equatorial Guinea for example. And there are no tensions (at least on the surface) in these countries. Yet, this does not mean that change will never come. Few would have thought former president Mugabe could ever be removed from power. He remained president for decades without any term limits on his presidency, and even when he signed a new constitution in 2013 imposing presidential term limits, he was still allowed to serve ten more years on top of his three decades (Chappel, 2017). He was however removed from power in November 2018, after 37 years in power (Chappel, 


\section{International Journal of Social Science and Economic Research}

ISSN: $2455-8834$

Volume:05, Issue:03 "March 2020"

2017). While it is true, that change in some countries (for example North Korea among others) might be unthinkable, we learn in Skocpol (1994) that dictatorial regimes are inevitably susceptible to resistance and revolution.

The point to make therefore, is that, laws which are passed based on objectionable sentiments such as greed, autocracy, hatred, prejudice, despotism, ill-will among others, are not good lawsat least in my view. Therefore, the sentiments I would support are positive, useful, and progressive sentiments. Those are the sentiments I would argue have a place in the law, and should have a place in the law (although I will agree that there might be challenges in determining what amounts to positive, useful, and progressive sentiments). Therefore, at this stage, it is necessary to mention that there is in fact and alternate view which can be deduced from the position taken by Raz (2009), who supports non conformity with rule of law in situations where the law (under a supposed rule of law) is devoid of social goals. Razz's position is that because social goals are above the law and should be above the law, laws which are against social goals or do not meet social goals under a supposed rule of law (for example laws against human rights and democracy), are not good laws and should not be obeyed. Going by Raz's view point, only positive sentiments should be welcomed when it comes to the creation, sustenance and administration of the law, and negative sentiments (for example, hate, greed, antipathy, autocracy, despotism and ill-will) should never inspire, create, sustain or manage laws. According to Raz, the rule of law is purposely to enable the law to promote social goals and social good. Therefore, if social goals are excluded from the law, the law will be worthless. Raz's position was based on his realization that countries that purport to be governed by the rule of law in fact have laws that do not serve social goals. He therefore believed that because the idea of rule of law is not always what it purports to be, the promotion of social goals (with good laws) should trump the idea of rule of law. Hence the focus of this article as has already been stated, is on good laws that stem from, and are administered, fostered, managed, revised or changed by positive sentiments.

A positive sentiment like compassion for example, is very important. Bandes (2017) underscores the significance of compassion in the law. She argues that compassion's importance lies in its ability to illuminate for the judge what is at stake for the litigant. She says it is compassion that commands the judge after seeing the perspective of the litigant, to help the litigant by applying the law. There is no doubt that a litigant will feel more validated if his or her interests, needs and expectations are recognized and realized through compassion, which is shown, not only by a judge acting within the law, but also expressed and articulated by the judge for all to hear. Hence a judge's expression of sentiments can make a lonely litigant feel supported, and can boost the 


\section{International Journal of Social Science and Economic Research}

ISSN: $2455-8834$

Volume:05, Issue:03 "March 2020"

confidence of a litigant. If potential litigants (especially the vulnerable, and those with limited means and support), know that judges can publicly resonate with them, and can publicly validate them, they will feel more confident to take their grievances to court, and will develop more trust and confidence in the justice system.

Bandes (2017) further contends that compassions cannot be excluded from the law, because judges are after all human beings, and so it is inevitable that they will be moved by sentiments such as sympathy, empathy, compassion and even anger, which sometimes they the judges, will be the first to admit. She used the case of DeShaney v Winnebago City Dept of Social Services (1989) as example of a case that concerned compassion (or lack thereof) of judges of the US Supreme Court. She explained the facts of that case: it concerned Joshua DeShaney, a four-yearold boy, who had suffered constant abuse from his father throughout his short life. The abuse was repeatedly reported to the Social Services, but they failed to protect him, and he ended up suffering irreparable brain damage. When the case went to the US Supreme Court, the US Supreme Court in delivering its judgments openly expressed sentiments, even though it ended up blaming Joshua's father and not the state. Bandes (2017) underscored that the Supreme

Court admitted that '...judges and lawyers, like other human are moved by natural sympathy in a case like this to find a way for Joshua and his mother to receive adequate compensation for the grievous harm inflicted on them...' (page 12)

Bandes (2017) indicated that the dissenting judge (Justice Blackmun) expressed more sentiments, expressing empathy, outrage and anger by saying among other things: '...Poor Joshua! Victim of repeated attacks by irresponsible, bullying, cowardly, and intemperate father, and abandoned by (the social service agency), who placed him in dangerous predicament and who knew or learned what was going on, and yet essentially did nothing...' (page14)

A news article by CNN (2018), reports that in the recently widely publicized case of the many young female American gymnasts who were sexually abused by their team physician Dr. Larry Nassar, the judge (who was no doubt moved by sentiments of anger and disgust), while delivering her judgment against the physician, made statements directed at the physician such as "I wouldn't send my dogs to you sir" ; "As much as it is my honor and privilege to hear the sister survivors, it is my honor and privilege to sentence you. Because, sir you do not deserve to walk outside a prison again"; and "Sir I'm giving you 175 years, which is 2,100 months. I have just signed your death warrant" (CNN, 2018 n.p). While some, like Marshall (2018), are of the view that the judge in this case overstepped her bounds and became a victim advocate by trying to be in sync with public sentiments, which they believe should never drive a judge's decision, the 


\section{International Journal of Social Science and Economic Research}

ISSN: $2455-8834$

Volume:05, Issue:03 "March 2020"

judge's expressions undoubtedly, would have resonated with many others-especially the victims and women who had previously suffered sexual abuse or are presently suffering sexual abuse. Her expressions were also no doubt a warning against present or potential sexual abusers, and a relief for many worried parents of young women and girls. Therefore, sentiments expressed by a judge can be a pacifier and reassurance, and can also direct and shape the punishment to deter recurrence, and help foster a more secure society. Sentiments can add character and charisma to the law, and one can argue that the formal application of rules should go hand in hand with sentiments. There is the argument that it is sentiments that lead judges to the decisions they make, not adherence to the law (Frank, 1931).

It is contended by Frank (1931) that it is the trained instincts of judges, plus their individual subjective receptivity to 'facts' that lead them to decisions they make, not the formal application of rules in consideration of objectively established facts. Bandes (2017) agreed that people do not begin with abstract principles. She suggests that people begin with moral intuitions that grow from their own experience and take shape within their own social worlds. She argues that personal experience, identification and compassion that flows for all sorts of reasons, articulated or, unarticulated will always influence legal decision making. Sentiments will influence the law and the application of the law, and in turn, the application of laws will also influence sentiments and prompting the retention of laws, or changes and amendments to laws. Under the circumstances, there appears to be an inextricably link between law and sentiments, and because of this link, it will appear that judges who say that sentiments have no place in the law, are in fact moved by sentiments (based on their own views about the case and the applicable laws) to say so.

By encouraging judges to express sentiments we also encourage their authenticity. If a judge is allowed to say what he or she genuinely feels, she is being encouraged to be authentic. By "authentic", I rely on a definition deduced from Rogers (1966), to mean that the judge does not deny to himself or herself the feelings he or she is experiencing, that he or she is willing to be transparent with those feelings, and does not present a façade or hide behind a mask of professionalism. Authenticity has been found to have a positive impact on life and productivity. Studies by Goldman \& Kernis (2002) and Kernis \& Goldman, (2005) suggest that the more authentic an individual, the more relatable, productive and fulfilled he or she becomes in life and in career. In addition to encouraging authenticity, the fact that the expression of sentiments involves a judge allowing his or her feelings and opinion to flow and be released, indicates that the expression of sentiments can have a cathartic effect on a judge, and can facilitate a positive 


\section{International Journal of Social Science and Economic Research}

ISSN: $2455-8834$

Volume:05, Issue:03 "March 2020"

change on the part of the judge who expresses them. Such a conclusion is supported by Powell's (2008) explication of catharsis as follows:

"The word catharsis is derived from the Greek word which is translated as

'cleansing' or 'purification'. Most of the definitions emphasize two essential components of catharsis: the emotional aspect (strong emotional expression and processing) and the cognitive aspect of catharsis (insight, new realization, and the unconscious becoming consciousness) and as a result-positive change..” (para.1)

The expression of sentiment (by words spoken, actions taken, or by simply allowing sentiments to flow in the self) can lead to emotional relief and heightened consciousness for the judge. However, it must be emphasized that the expression of sentiments can only encourage authenticity of a judge if the sentiments to be expressed or are expressed by him or her are genuine, and not made for pleasing others or oneself. Moreover, the study by Kernis \&Goldman (2005) also found that authenticity does not always have a positive impact on the person who strives to be authentic. They found that self-knowledge may be too painful for some to handle, leading to tragic consequences, meaning that authenticity must be hailed cautiously. Moreover, it should also be borne in mind that judges are bound by certain rules of conduct (for example our own Judges (Supplementary Code of Conduct) Act, which can make them feel restricted to express any sentiment they have, and hence restrict their authenticity.

Therefore, while a judge might appear mechanical and inhumane if he or she does not express sentiments-especially sentiments of compassion, and sympathy, it is also important to know that they face professional restrictions, and these restrictions must be borne in mind while questioning or criticizing a judge for not expressing compassion or sympathy. Clearly, there are challenges in encouraging judges to express sentiments. The challenges are the reason for the objections, which will be addressed in the next segment.

\section{Objections to sentiments}

Bandes (2016), while recognizing that emotions are deeply intertwined with the reasoning process and hence cannot be excluded from legal reasoning, also recognized that emotions can be based on unsupported or mistaken notions, and so their inclusion in the reasoning process can lead to injustice or compromise justice. So, in Bandes (2017), she cautions against the tendency to uncritically embrace sentiments, emphasizing that sentiments can stem from inaccurate perceptions. She said as much as sentiments can lead to the right decision, they can also lead to the wrong decision, especially if they are based on wrong assumptions, misconceptions and 


\section{International Journal of Social Science and Economic Research}

ISSN: $2455-8834$

Volume:05, Issue:03 "March 2020"

misinterpretations. She points out a judge while expressing sentiments, judges may use the opportunity to support and pander to the prejudices and biases of litigants, not only to cause outrage, but also to cause injustice. For example, a judge might share the same racist sentiments with a litigant prompting his sympathy and understanding for the litigant, and causing injustice to the victim. She also points out that a judge may choose to express sentiments in objectionable ways as to alienate litigants and the public, causing societal tensions. Perhaps an example for this could be sentiment of sympathy toward a victim of theft and that of anger towards the convicted thief, prompting a judge in convicting and passing sentence against the thief, to call the thief a "dirty, ugly, slimy Christian/Muslim thief". Such expression will clearly upset Christians or Muslims. And others who might not be aligned to a particular faith might think it unnecessary to use to use the words "dirty, ugly slimy".

It is necessary to bear in mind that there is a dark side to judges expressing sentiments, and that a judge by expressing sentiments can in fact promote hatred, division and discord, to cause, perpetuate, or escalate conflict. Indeed, in this jurisdiction Rule 6(4) of the Judges (Supplementary Code of Conduct) Act (2009) requires a judge to avoid insulting and making improper remarks about litigants, witnesses and counsel. Although there is no guideline as to what would amount to "insulting" or "improper remarks", it is necessary that judges bear this Rule in mind when they express sentiments. Bandes (2017) point out that judges can often rely on wrong assumptions which trigger their emotions for the wrong reasons and can cause injustice. She warns against judges relying on assumptions, and stresses that even if assumptions are widespread, they can still cause injustice, because people do not react to situations or do things in the same way every time, and there is no one size fits all. And so Anleu, Rottman\& Mack (2016) underscore how the expression of sentiments can lead to misconduct and serious consequences for a judge. They give examples, including the case of re Barker (2010), which they explained included the following exchange between a male judge and a woman litigant who was not willing to let her daughter spend time with her estranged husband:

"Judge: You need some serious help.

Ms. P: Okay

Judge: Because you have no clue what it is to be a parent.

Ms. P: Okay, he has severe mental illness.

Judge: Ma'am keep your mouth quiet. When I talk you don't talk back to me.

I don't know who you think you're talking to, but you do not dare talk back to me. You understand that? 


\section{International Journal of Social Science and Economic Research}

ISSN: $2455-8834$

Volume:05, Issue:03 "March 2020"

Ms. P: Yes

Judge: Then obey it. I'm not some friend of yours out on the street. I'm a Superior Court Judge that demands the respect of my position, and you will give it to me. And you will not convince me that it's okay for your daughter to go spend time with strangers, but you can't with her own father, because you know what you forgot? Let me remind you. There's only one reason why he's her father, that's the decision you made.

\section{Ms. P: And it was a bad one}

Judge: Ma'am-so, what does that tell me about your judgment? If you made a bad decision choosing him as a father, why should I believe anything about your judgment today? Well, you just admitted, you've got bad judgment.

Ms. P: I made a mistake. We all make mistakes, I'm human.

Judge: And you're making a huge mistake when you tell me today that you don't think your daughter deserves to be with her father.

Judge: Ma'am, don't talk back to me. Who do you think you are? Any parent that takes steps to limit the other parent's time with the child doesn't qualify to be a parent. You want to do what's good for your daughter, encourage her to go spend time with her father. That's her father not a stranger. He has equal rights, as you. You don't get any preference because you're her mother. And

if you made a mistake, too bad. We're not going to punish your daughter today because of your poor judgment, and I am not going to allow your poor judgment to continue. You understand that?...

Judge:...Y You know what happens if you disobey a court order? Ma'am do you know what happens?

Ms. P: Yes I understand what happen

Judge: You will be sitting over there with this guy right here [referring to a shackled prisoner sitting in the courtroom]. This is not a request. I am telling you it will happen.

Ms. P: Okay, Your Honor...” (pp. 67-68)

As pointed out by Anleu et al (2016), the judge's statements were largely based on his own belief about child rearing. This exchange shows how a judge's sentiments can cloud his or her decisions for the worse. The exchange not only contained objectionable statements of disdain for the mother of the child, it also contains threatening language, which made it even worse. What this case also shows is that there is a risk that expression of sentiments might amount to, include, or lead to use of threatening language, and hence the need for restraint and decorum when expressing sentiments. Anleu et al (2016) were of the view that although judicial behavior that 


\section{International Journal of Social Science and Economic Research}

ISSN: $2455-8834$

Volume:05, Issue:03 "March 2020"

incorporates human personality and feeling may enhance public confidence in the courts and the judiciary, some human and emotional judicial conduct might suggest that the judge is not as detached and impartial as he ought to be, and thus lead to a reduced confidence in the judiciary, because expressions of sentiments can invite criticisms of favoritism and bias against a judge and bring a judiciary into disrepute. Expressions of sentiments can make a judge look or sound comical and silly. It is doubtful that the judge in re Barker would be proud of himself when he sees or hear tapings of himself making the said statements. A judge's expression of sentiments can cause unwanted negative publicity for judges and the judiciary. Thus, judges should be wary that expressions of sentiments might end up eroding the dignity and reverence attached to their office and indeed their person, making them the subject of ridicule and contempt. In the example given by Anleu et al (2016), the judge appeared to be a bully and a megalomaniac.

Therefore, the importance of restraint and humility in judicial expression of sentiments cannot be over emphasized. Self-awareness, restraint and humility are key recommendations for judges who tend to express sentiments (Bandes, 2017) and (Frank, 1931). Like everybody else, judges are entitled to freedom of expression, and one might argue that this is one very good reason why they should be free to express their sentiments. This entitlement is recognized in this jurisdiction by Rule 9 of the Judges (Supplementary Code of Conduct) Act (2009). However, Rule 9 imposes limits and also provides that a judge must avoid any debate that would reasonably undermine confidence in his or her impartiality. It must therefore be emphasized that, a judge must express sentiments responsibly.

\section{Conclusion and Recommendations}

It must be stressed that there is a huge responsibility on the judge who chooses to express sentiments. Bandes (2017), who extensively discussed about compassion in the law, undoubtedly appreciates the value of sentiments in the law. Yet, she also recognized the possible pitfalls of sentiments as already highlighted, and therefore recommends that self-awareness must go hand in hand with the expression of sentiments. In essence Bandes (2017) believes that a judge who expresses sentiments must be self-aware and must be willing to recognize that his or her own view points about the needs, wishes, aspirations and expectations of litigants, which prompt certain sentiments in him or her, might very well be inaccurate and objectionable. Therefore, judges must be willing to critically consider the points of view they hold about the feelings, needs, wishes, aspirations and expectations of litigants before expressing sentiments or acting on sentiments. Bandes (2017) believes that a judge-especially a judge who expresses sentiments, must be humble, open, and cautious, because it is the humble, open and cautious judge, who is willing to be critical of his or her own sentiments before expressing them or acting on them. She 


\section{International Journal of Social Science and Economic Research}

ISSN: $2455-8834$

Volume:05, Issue:03 "March 2020"

therefor cautions against the tendency to embrace sentiments uncritically. She also emphasizes that context matters, because while a particular sentiment might be appropriate in a particular case, it might not be appropriate in another. If sentiment is to be useful, it must be relevant to the context in which it is applied. Judges should therefore pay attention to context, and not assume that one size fits all. Bandes (2016) had observed that when legal rules or decisions of judges are based on mistaken or unsupported opinions, perceptions or assumptions, justice maybe compromised. She referred to the case of Gonzales v Cahart (2007) as example of a case where the US

Supreme Court's decision upholding a rule against late term abortion, was based on assumptions which she says were contradicted and unsupported by available evidence.

Therefore, sentiments must not compromise justice.

Like Bandes (2016) \& (2017), Frank (1931) suggests that the judge, while engaged in deliberations, must constantly engage in consideration of opposing possibilities and rigorous introspection. He believed this will help the judge to be more self-aware, and be able to keep in check his or her prejudices, biases, beliefs, assumptions and antipathies among other things, and so ensure that his or her decision is not tainted with bias and prejudice. Frank believed that as long as judges engage in introspection, and are able to detect and hold in check their prejudices and biases, they need not exclude their sentiments in their deliberations. However, Frank also believed that it is not enough that the judge is aware of his or her biases and prejudices, he also believed that the judge must also develop the right biases and prejudices (the biases and prejudices that support and further the aims of the law and the evidence at hand), not ones that are perverse.

In effect, what is important is that judges are not enslaved and driven solely or predominantly by sentiments in reaching their decisions, and that sentiments are not allowed to displace a judge's commitment to the law and to the evidence. In this jurisdiction, Rule 6(2) of the Judges (Supplementary Code of Conduct) Act (2009) requires a judge to strive to ensure that his or her conduct in and out of court maintains and enhances confidence and his or her impartiality and that of the judiciary. Nevertheless, the duty to be impartial and to enhance confidence, should not automatically or necessarily exclude the responsible expression of sentiments- especially if the judge's decision is supported by the law and the evidence at hand, and the expression of his or her sentiments does not offend against the provisions of the rules of judicial conduct. My view therefore, is that caution is key for the judge who expresses sentiments.

References

www.ijsser.org

Copyright (C) IJSSER 2020, All rights reserved

Page 765 


\section{International Journal of Social Science and Economic Research}

ISSN: $2455-8834$

Volume:05, Issue:03 "March 2020"

Abrams, K., \&Keren, H. (2010). Who's afraid of law and emotions? Minnesota Law Review

Aljazeera News (2013, May, 22) “Zimbabwe's Mugabe signs new constitution”.

Aljazeera.com https://www.aljazeera.com>africa

Aljazeera News (2018, May, 22) "Burundi backs new constitution extending presidential term limits". Aljazeera.comhttps://Aljazeera.com>Africa

Anleu, S.R.; Rottman, D., \& Mack, K. (2016). The emotional dimension of judging

American Judges Association Court Review. Vol. 52, 60

Ba, D., Christenssen, S., McAllister, E., \& Roche, A., (2018, April 19). "Senegal capital erupts in protest over new election law”. Reutershttps://www.reuters.com >article

Bandes, S. (2017). Compassion and the rule of law. International Journal of Law in Context, 13(2)

Bandes, S. (Ed.). (2000). The passions of law. NYU Press

Bandes, S.A. (2011). Moral Imagination in judging. Washington Law Review, 51:1-24

Bandes, S.A. (2016). What roles do emotions play in the law? Emotion Researcherhttp://emotionresearcher.com/what-roles-do-emotions-play-in-the-law/

BBC News (2018, Mat 26). "Irish Abortion Referendum: Exit Polls suggest landslide for Repeal" bbc.comwww.bbc.com>news

Cattell, R.B. \& Child, D. (1975). Motivation and dynamic structure. John Wiley \& Sons

Chappel, B. (2017, November 15) “Zimbabwe's Mugabe out of power for first time since 1980s as military takes control". National Public Radio. https://www.npr.org

CNN (2018, January, 24). "Read Judge Rosemarie Aquilina's Powerful Statement to Larry Nassar" (2018, January 24) cnn.com $\underline{\text { https://www.cnn.com>judge-ro }}$

D’Amato, A. (2011). On the connection between law and justice. Faculty Working Papers. 2. https://scholarlycommons.law.northwestern.edu/facultyworkingpapers/2

Dietrich (2014). A brief introduction to transrational peace research and elicitive conflict transformation. Journal of Conflictology, 5(2), 6 


\section{International Journal of Social Science and Economic Research}

ISSN: $2455-8834$

Volume:05, Issue:03 "March 2020"

Dietrich, W. (2006). A call for transrational peaces. University of Innsbruckhttp://www.ubk.ac

Drury, F., \& Fouche, A. (2018, May 21). "Burundi votes to extend Nkurunziza rule" BBC News. http://www.bbc.co.uk/news/li...

English Oxford Living Dictionaries (n.d.) https://en.oxforddictinaries.com

Eskeridge Jr., W.N. (1999). Comparative law and the same sex marriage debate: a step by-step approach toward state recognition. McGeorge L. Rev. 31, 641

Franco, T. (2017) 10 facts about the Burundi unrest. The Borgen Project. https://borgenproject.org

Frank, J. (1931). Law and the modern mind. Transaction Publishers

Galtung, J. (1969). Violence, peace and peace research. Journal of Peace Research, 6(3): 167191

Media Legal Defence Initiative (2018, May,16). “Gambia: A mixed result as the Supreme Court delivers judgment in important constitutional challenges to free speech laws". https://www.mediadefence.org

Goldman, B.M., \& Kernis, M.H. (2002). The role of authenticity in healthy psychological functioning and subjective well-being. Annals of the American Psychotherapy Association, 5(6), $18-21$

Harvey, D., \& Braun, B. (1996). Justice, nature and the geography of difference Oxford: Blackwell

Hirschel-Burns, T. (2015). Burkina Faso protesters remove Blaise Campaore from power, 2014. Global Nonviolent Action Database.https://nvdatabase.swarthmore.edu

Hovey, E.H. (2015). What are sentiment, affect and emotion? Applying the methodology of Michael Zock to sentiment analysis. (Gala, N., Rapp, R.,Bel-Enguix, G. Eds.).

Language Production, Cognition, and the Lexicon, Text, Speech and Language Technology, Vol. 48.

Jobarteh, M. (2018). From dictatorship to new constitution in The Gambia: Issues and concerns. Constitution.net www.constituionnet.org 


\section{International Journal of Social Science and Economic Research}

ISSN: $2455-8834$

Volume:05, Issue:03 "March 2020"

Jones, R. (September 27, 2017) (untitled) www.telegraph.co.uk

Kendall-Taylor, A., \& Frantz, E. (2014, November 12). "Burkina Faso and the growing vulnerability of autocrats to revolt". The Washington Post. https://www.washingtonpost.com

Kernis, M.H., \& Goldman, B.M. (2005). From thought and experience to behavior and interpersonal relationships: A multicomponent conceptualization of authenticity.

On building, defending and regulating the self: A psychological perspective, 3152

Khazan, O. (2016, November 9). "How Obamacare helped Trump”. The Atlantic.

https://www.theatlantic.com

Kline, P. (2013). The handbook of psychological testing. Routledge

Landis, E.S. (1961). South African Apartheid Legislation 1: Fundamental structure. The

Yale Law Journal, 71 (1), 1-52

Landis, E.S. (1962). South African Apartheid Legislation 11: extension, enforcement and perpetuation. Yale Law Journal, 71(3), 437-500

Lederach, J.P. (1998). Building peace: Sustainable reconciliation in divided societies. Unites States Institute of Peace

Marshall, R. (2018, January 25). "The moment the judge in the Larry Nassar case crossed a line". vox.comhttps://www.vox.com

Masket, S.E., \& Green, S. (2011). The electoral impact of roll call votes in the 2010

Congressional Elections. Annual Meeting of the Midwest Science Association, Chicago

McDougall, W. (1926) An introduction to social psychology (revised edition) Boston:

John W. Luce \& Co.

Ndabaneh, S. (2017). New Gambia and the remaking of the constitution. Law Hub

Gambiawww.lawhubgambia.com 


\section{International Journal of Social Science and Economic Research}

ISSN: $2455-8834$

Volume:05, Issue:03 "March 2020"

Ndulo, M., \& Lulo, S. (2010). Free and fair elections, violence and conflict. Harvard ILG Online, Vol. 51

Newkirk 11, V. R. (2017, November 30). "Republican obstruction of Obamacare helped put Trump in the White House", The Atlantic. https://www.theatlantic.com

Pilgrim, D. (2000). What was Jim Crow? Ferris State University 16, 2007

Powell, E. (2008). Catharsis in psychology and beyond: A historic overview. The Primal

Psychotherapy Page. www.primal-page.com

Raz, J. (2009). The authority of law: Essays on law and morality. Oxford University Press on Demand

Roche, H. (2017). The Syrian crisis: realist interests and responses. Academia www.academia.edu>THE_SYRIAN-CR...

Rogers, C.R. (1966). Client-centered therapy. In Arieti (Ed.) American handbook of psychiatry (Vol.3, pp183-200). New York: Basic Books

Rowell, A. (2018). Legal rules, beliefs and aspirations. University of Illinois College of Law

Sajó, A. (2016). Emotions in constitutional institutions. Emotion Review. Vol.8(1),44-49

Sanneh, K. (2018, May 15). "Supreme Court decision worries journalist Fatty" The Point Newspaper thepoint.gm

Skocpol, T. (1994). Social revolutions in the modern world. Cambridge University Press

Weinstein, J.A. (1993). An Irish solution to an Irish problem: Ireland's struggle with abortion law. Ariz. J. Int'l \& Comp. L. 10, 165.

\section{Case law}

Antoine Banna v Ocean View Resort Limited (2002-2008) GLR VOL.1,1

DeShaney v Winnebago City. Dept of Social Services, 489 U.S. 189, 109 S.CT. 998 (1989)

Evans v Bartlam [1937] AC 473

Gambia Press Union \& Ors v The Attorney General Civil Suit No. 1/2014 
International Journal of Social Science and Economic Research

ISSN: 2455-8834

Volume:05, Issue:03 "March 2020"

Gonzales v Cahart, 550 U.S. 124 (2007)

Haro Company Limited v Ousman Jallow (2002-2008) GLR VOL.1, 128

Re Barker, No. ACJC 2010-151 (NJ., May 2, 2011) (Presentment), available at http://www.judiciary.state.nj.us/pressrel/ACJC\%20Presentment\%20Max\%20A\%Baker.p df

Sallah \& Ors v Clerk of National Assembly \& Ors (2002-2008) GLR, Vol. 1, 229 Sankung Sillah \& Sons Ltd v Gambia Ports Authority (1960-1993) GR, 49

\section{Laws and Instruments}

African Charter on Human and People's Rights (1986) www.achpr.org.instruments.achpr

Constitution of the Republic of The Gambia (1970) www.gambia.dk.>The_Gambia_Constitution

Constitution of the Republic of The Gambia (1997) https://www.assembly.gov.gm>uploads> Elections (Amendment) Act 2017 European Convention on Human Rights (1953) https://www.www.echr.coe.int $>$ Documents

Independent Electoral Commission (Amendment) Act 2015

Oaths Act (1965) Cap 35:05 Laws of The Gambia

Universal Declaration of Human Rights (1948) www.un.org.udhr_booklet_en_web 